\title{
TAKING STATELESSNESS SERIOUSLY
}

\author{
PHILLIP COLE
}

My first encounter with the idea of statelessness happened when I was invited to participate in the Statelessness and Transcontinental Migration Conference at the United Nations University Institute in Barcelona in 2014. I gave a short paper on 'The Philosophy and Politics of Membership' which, I have to confess, did not venture very far into the landscape of statelessness. The invitation came because of my work on the ethics of international migration and on refugees and asylum, and my initial thought in accepting the invitation was that what I had to say about migration and membership would be relevant to the conference's topic. The paper was well received, but I was troubled by the fact that, in the end, it did not address statelessness, and that, despite writing and editing a number of books and contributing chapters and articles on the ethics of international migration, I had never included statelessness in any of those discussions.

Fortunately, the Barcelona conference kick-started a project with Tendayi Bloom and Katherine Tonkiss that resulted in the edited collection Understanding Statelessness published in $2017 .{ }^{1}$ In the course of that project and writing my own chapter, 'Insider Theory and the Construction of Statelessness', I came to realise that I could not simply subsume the subject within the arguments I had already made regarding migration and refugees, and that statelessness was a distinct question with its own dimensions. But, at the same time, it was a question that enabled me to reflect on my work on migration, because at the heart of all that work was the problematic concept of political membership, and the issue of statelessness has, or ought to have, a fundamental impact on how we think about political membership itself.

However, there are challenges in bringing the concept of statelessness into 'mainstream' political theory, or at least that part of political theory that examines migration and membership. Part of the problem is that discussions around the ethics of migration take place within two framing paradigms: the paradigm of voluntary movement and the paradigm of original membership. The subject of the discussion is the person who voluntarily moves across international borders and who, while perhaps (but not necessarily) seeking membership of the state they have entered, is already a member of another state. Therefore, if the new state allows them entry but refuses them membership, they have another state that recognises them; and if the new state refuses them entry altogether, they have another state where they have the right of residence - they have a political home. This allows us to structure the discussion around a series of analogies concerning rights of entry and exit, to show that it is entirely appropriate for states to refuse the right of entry, without noticing that those analogies are almost entirely beside

* Senior Lecturer in Politics and International Relations at the University of the West of England, Bristol.

1 Tendayi Bloom, Katherine Tonkiss and Phillip Cole, Understanding Statelessness (Routledge 2017). 
the point. For example, the analogy with marriage is often used to demonstrate the view that, while there is a universal right to leave any state, there need not be any corresponding right to enter. David Miller says:

Obviously, if no state were ever willing to grant entry rights to people who were not already its citizens, the right of exit would have no value. But suppose states are generally willing to consider entry applications from people who want to migrate, and that most people would get offers from at least one such state: then in this respect the position as far as the right of exit goes is pretty much the same as with the right to marry, where by no means everybody is able to wed the partner they would ideally like to have, but most have the opportunity to marry someone. ${ }^{2}$

The point is that while everyone has the right to marry, they do not have the right to enter into any particular marriage relationship they choose - the proposed partner has the right to refuse. One does not have the right to marry a particular person, and one does not have the right to enter a particular state.

Although Miller is talking about the right of entry, he is using it to discuss the right of exit, to show that the right of exit does not entail a right to enter anywhere else. However, when one exits a marriage, one does not need to have another marriage to enter, and this is the same with many associations - the right of exit does not require that one has another association to enter into. There is, if you like, a 'space' one can enter without difficulty, and where one can remain indefinitely. One never needs to enter into marriage, or a golf club, or any of the other kinds of associations that are often appealed to in the immigration debate. This is why it is plausible to suppose that here the right to exit does not entail a right of entry, because the right to exit does not depend on entry elsewhere. One can enact one's right of exit from these associations and never enter another one, and what is crucial to notice is the existence of this 'space' outside of these associations that one can enter without restriction, and where one can develop one's life prospects perfectly well if one wishes.

This is dramatically and importantly not the case when it comes to nation-states. Exit from this kind of association does depend on being able to enter another one, both territorially and civilly. There is the 'space' of statelessness, but it is not one anybody would wish to enter - it is deeply problematic and dangerous, and nobody can develop their life prospects in that space to any degree. While it is plausible to suppose that the right of exit does not entail a right of entry into the other kinds of associations, like marriages and golf clubs (because there is no need to enter another association in order to enact the right to leave), in the case of the nation-state there is a need to enter another association in order to enact the right to leave. So in this case it is plausible to suppose that the right of exit does imply the right of entry. The absence of the concept, indeed the fact, of statelessness from the political theory of immigration has had an importantly limiting effect on the discussion. Original membership is simply assumed. ${ }^{3}$

Discussions of refugees and asylum seekers take place within a slightly different theoretical landscape. There is still the paradigm of original membership, in that the refugee is considered a member of another state such that the receiving state can grant them temporary protection until it is considered safe for them to return to their home state. In the longer term, receiving states may grant permanent

2 David Miller, National Responsibility and Global Justice (Oxford University Press 2007) 209.

3 See generally Christopher Heath Wellman and Phillip Cole, Debating the Ethics of Immigration: Is There a Right to Exclude? (Oxford University Press 2011) 202-10. 
residence and membership, but the paradigm of original membership remains. But another paradigm also operates here - the paradigm of forced displacement, as opposed to voluntary movement: the refugee is someone who has been forced to leave their original state because of persecution.

While it may seem obvious that the stateless do not fit into the first two paradigms of original membership and voluntary movement, it is the fact that they do not fit into the third paradigm of forced displacement that is perhaps the most important feature. The temptation is to think that, while the stateless are not included within the political theory of voluntary migration, they must be covered by the political theory of forced displacement, and so our extensive discussions of refugees and issues of asylum and protection need only be tweaked here and there to include them. This, I suspect, was my frame of mind as I prepared for the Barcelona conference.

However, it does not take long to realise that statelessness is a distinct issue from forced displacement in that many of the most problematic case studies of the former have nothing to do with the latter. The most dramatic example is, of course, the Rohingya of Myanmar. While vast numbers of the Rohingya have been forcibly displaced from Myanmar, ${ }^{4}$ their statelessness was not caused by that forced displacement - it pre-dated it and indeed we might consider the causality to be the other way round to some extent. ${ }^{5}$ A case study I discussed with my students was that of the 'Hill Tamils' of Sri Lanka, a population of around 168 000 people rendered stateless when Ceylon became independent in 1948. ${ }^{6}$ The new citizenship laws required that those born before independence prove that two generations of their families were born within the territory, plus a period of 10years uninterrupted residence accompanied by an income requirement - laws specifically designed to target the Hill Tamils amongst others. ${ }^{7}$ Another example is the Karana in Madagascar, with a population of around 20000 , present for more than a century, but with a significant portion of stateless persons. ${ }^{8}$ The Karana were not given citizenship on independence in 1960 because they were not considered to be ethnically Malagasy, and attempts by individuals to obtain citizenship were generally unsuccessful. ${ }^{9}$ There are similar examples of the Makonde and the Pemba in Kenya, of people in a condition of statelessness within the state they were born in and their parents were born in - their statelessness is not caused by forced displacement, and has only a tenuous connection with migration. ${ }^{10}$

4 United Nations Office for the Coordination of Humanitarian Affairs, 'Rohingya Refugee Crisis' (March 2019) <https://www.unocha.org/rohingya-refugee-crisis>.

5 Amal de Chickera, 'Statelessness and Identity in the Rohingya Refugee Crisis' Humanitarian Practice Network (October 2018) <https://odihpn.org/magazine/statelessness-identityrohingya-refugee-crisis/>.

6 United Nations High Commissioner for Refugees, Good Practices Paper - Action 1: Resolving Existing Major Situations of Statelessness (Good Practice Paper, 23 February 2015) $<$ http://www.refworld.org/docid/54e75a244.html $>$.

7 For a discussion of the Hill Tamils, see United Nations High Commissioner for Refugees, Resolving Existing Major Situations of Statelessness (Good Practice Paper, 2014) $<$ www.refworld.org/pdfid/54e75a244.pdf. $>$.

8 United Nations High Commissioner for Refugees, 'This Is Our Home' - Stateless Minorities and Their Search for Citizenship (Report, November 2017, $<$ www.unhcr.org/ibelong/stateless-minorities/>.

9 ibid.

10 See generally ibid. 
It was through teaching statelessness for the first time that I became more aware of the power of the forced-displacement paradigm here. I set a question: 'Does statelessness pose a distinct challenge for the international system? If so, how should it be addressed?', and some students chose to answer it, using the Rohingya as a key case study. But in marking the essays I realised that the students were trapped within the paradigm - the challenge they believed statelessness posed for the international system was one of forced displacement, and could only be addressed through strengthening the rights of refugees. The case study of the Rohingya, without fail, was discussed in relation to their forced displacement from Myanmar - in other words as refugees rather than as stateless persons. I take some responsibility for this, as I embedded the topic in a section of the module titled 'Global Migration', and sandwiched it among discussions of migration and forced displacement, so that I placed it within the 'traditional' paradigms, and could not reasonably expect students to 'displace' it. I need to think seriously about how and where I teach students statelessness next time round, enabling them to see that the stateless are 'dis-placed' in a distinctive and particularly dangerous way.

The temptation to believe we can include the stateless within our political theory with a minor tweak to our discussions of forced displacement and protection for refugees is misplaced. We need to radically rethink how we understand membership, indeed how we do political theory as such. The implication is that we need to break out of the paradigms the discussion of statelessness is currently locked into - of original membership, of voluntary movement and of forced displacement. And we may need to break out of the biggest paradigm of all, one that political theory itself is locked into: that of political membership. One solution to the challenge of statelessness is that we all become stateless. If membership is locked into the nation-state system and if that system systematically produces statelessness, then we have to look beyond that system. But to imagine a world without membership is a step few are prepared to take, either in practice or in their political imagination.

I wait with interest to see what impact the discussion of statelessness will have on political practice and political theory - whether it will ever be taken as seriously as it should be, given its radical implications. I hope I have made and will continue to make some contribution to that discussion, both through research and teaching, and welcome the establishment of the Statelessness and Citizenship Review as a space for those developments. 